\title{
Profesionalitas Guru
}

\author{
Aulia Insan \\ Email: 2010111210002@mhs.ulm.ac.id \\ Program Studi Pendidikan Sejarah Fakultas Keguruan dan Ilmu Pendidikan \\ Universitas Lambung Mangkurat \\ Banjarmasin
}

\begin{abstract}
Abstrak
Guru adalah pendidik dan pengajar pada pendidikan anak usia dini jalur sekolah atau pendidikan formal, pendidikan dasar, dan pendidikan menengah. Guru-guru seperti ini harus mempunyai semacam kualifikasi formal. Dalam definisi yang lebih luas, setiap orang yang mengajarkan suatu hal yang baru dapat juga dianggap seorang guru. Secara formal, guru adalah seorang pengajar di sekolah negeri ataupun swasta yang memiliki kemampuan berdasarkan latar belakang pendidikan formal minimal berstatus sarjana, dan telah memiliki ketetapan hukum yang sah sebagai guru berdasarkan undang-undang guru dan dosen yang berlaku di Indonesia.
\end{abstract}

\section{PENDAHULUAN}

Konsep profesi adalah suatu kegiatan dimana kegiatan tersebut pada dasarnya harus dikerjakan oleh orang yang memiliki keahlian, kemahiran, dan kecakapan dengan tujuan memenuhi standar dan hal ini memerlukan riwayat pendidikan. Profesi guru adalah suatu pekerjaan yang mana terdapat tugas-tugas dan syarat-syarat yang harus dipenuhi oleh seorang guru, tentunya guru harus dedikatif dalam sesuai dengan bidang keahlian dan selalu improvisasi diri.

\section{PERAN GURU SEBAGAI SEBUAH PROFESI}

Guru diklasifikasikan sebagai sebuah profesi disebabkan oleh pekerjaannya dimana sebagai guru harus memiliki keahlian khusus dan tidak dapat dilakukan oleh sembarangan orang yang diluar dari bidang kependidikan. Guru memiliki peran sebagai pendidik yaitu menjadi tokoh/panutan peserta didik, sebagai pengajar mengajarkan peserta didik pengetahuan dan kemampuan, dan sebagai pembimbing bertanggungjawab dalam kegiatan belajar pembelajaran. 
Guru juga memiliki hak dimana guru berhak memperoleh penghasilan diatas kebutuhan hidup/jaminan sejahtera, memperoleh perlindungan dalam melaksanakan tugas dan hak atas kekayaan intelektual, memiliki kesempatan meningkatkan kompetensi, dan memperoleh sarana prasarana dalam mendidik. Kewajiban guru yaitu melaksanakan proses pembelajaran yang bermutu,Meningkatkan dan mengembangkan kualifikasi akademik dan kompetensi secara berkelanjutan, bertindak objektif dan tidak diskriminatif, dan memelihara dan memupuk persatuan dan kesatuan bangsa

\section{GURU INDONESIA DAN TANTANGAN PROFESIONALISME}

Karena guru yang profesional dapat memenuhi ketetapan kurikulum yang telah dibuat oleh menteri pendidikan dengan tujuan guru yang profesional dapat memenuhi tujuan atau target pemerintah dalam mengembangkan pendidikan di Indonesia.

Komponen kompetensi yang harus dimiliki guru agar disebut sebagai guru yaitu, kompetensi profesional adalah kemampuan seorang guru dalam mengelola proses belajar mengajar, kompetensi pedagogik berkaitan erat dengan kemampuan guru dalam memahami proses pembelajaran, kompetensi sosial adalah kemampuan guru sebagai pendidik untuk berkomunikasi dan berinteraksi yang baik dengan warga sekolah maupun warga dimana guru berada, dan kompetensi kepribadian guru yang patut ditiru merupakan filosofi yang menunjukkan kemampuan kepribadian.

\section{SIMPULAN}

Guru adalah seorang pendidik yang sangat diperlukan bagi perkembangan dunia pendidikan dimana tidak semua orang bisa menjadi seorang guru. Profesi guru adalah suatu pekerjaan yang mana terdapat tugas-tugas dan syarat-syarat yang harus dipenuhi oleh seorang guru, tentunya guru harus dedikatif dalam sesuai dengan bidang keahlian dan selalu improvisasi diri.

Guru harus berdedikasi terhadap pekerjaannya sesuai dengan hak dan kewajibannya. Profesionalisme guru dituntut memenuhi kurikulum yang digunakan sebagai pedoman pembelajaran agar dapat memenuhi target dari perkembangan pendidikan dan dapat mencetak bibit unggul bangsa. 


\section{REFERENSI}

Efendi, I., Prawitasari, M., \& Susanto, H. (2021). Implementasi Penilaian Pembelajaran Pada Kurikulum 2013 Mata Pelajaran Sejarah. Prabayaksa: Journal of History Education, 1(1), 21-25.

Susanto, H. (2020). Profesi Keguruan. Banjarmasin: FKIP Universitas Lambung Mangkurat.

Susanto, H., \& Akmal, H. (2018). Efektivitas Penggunaan Aplikasi Pembelajaran Berbasis Mobile Smartphone Sebagai Media Pengenalan Sejarah Lokal Masa Revolusi Fisik Di Kalimantan Selatan Pada Siswa Sekolah Menengah Atas. HISTORIA: Jurnal Program Studi Pendidikan Sejarah, 6(2), 197-206.

Susanto, H., Irmawati, I., Akmal, H., \& Abbas, E. W. (2021). Media Film Dokumenter Masuknya Islam Ke Nusantara dan Pengaruhnya Terhadap Keterampilan Berpikir Kritis Siswa. HISTORIA: Jurnal Program Studi Pendidikan Sejarah, 9(1).

Syaharuddin, S., \& Susanto, H. (2019). Sejarah Pendidikan Indonesia (Era Pra Kolonialisme Nusantara sampai Reformasi). Banjarmasin: FKIP Universitas Lambung Mangkurat. 